\title{
Socio Economic Status of Handloom Weavers in Warangal Urban District
}

\author{
M. Gayathri Devi ${ }^{*}$, V. Vijaya Lakshmi ${ }^{2}$, Induri Rajitha ${ }^{3}$ and S.L. Kameswari ${ }^{4}$ \\ ${ }^{1}$ Department of Resource Management and Consumer Sciences, \\ College of Home Science, PJTSAU, Hyderabad, India \\ ${ }^{2}$ FRM -AICRP (Home Science), PJTSAU, Hyderabad, India \\ ${ }^{3}$ NIFT, Hyderabad, India \\ ${ }^{4}$ Department of Extension Education and Management, College of Home Science, PJTSAU, \\ Hyderabad, India \\ *Corresponding author
}

\section{A B S T R A C T}

\begin{tabular}{|l|}
\hline Ke y w o r d s \\
Gender, \\
Handlooms, \\
Income, Socio - \\
economic status, \\
Weaving
\end{tabular}

\section{Introduction}

Handloom industry inhabits an exceptional place in the country for its exclusive arts and artifacts prepared by handloom weavers. This offers direct and indirect employment to more than 43 lakh weavers and related workers. Handloom sector is responsible for approximately 15 per cent of the cloth production in the country and also to export earnings of US\$ 199 million during April-
Handloom sector is a leading sphere in the country after agriculture in providing direct and indirect employment to more than 43 lakh weavers and allied workers. The present study was taken up to find out the socio economic status of handloom weavers. Purposive random sampling method was used to select the 120durrie weavers from Warangal urban. Income, educational qualification, and profession were taken into consideration to compute socioeconomic status. Findings revealed that gender ratio in the occupation was3:1. Most of the young adult and middle aged women weavers were involved in weaving and the percentage was significantly higher than men weavers. There was a significant positive relationship between socio economic status and BMI, r (118) =0.0512, $\mathrm{p}<0.1$. There is a significant positive relationship between socio economic status and working hours, $\mathrm{r}(118)=0.068, \mathrm{p}<0.1$. It can be concluded that individuals who spend active time on weaving will earn more amount of remuneration, so automatically socioeconomic status of the individual will be enhanced. 


\section{Materials and Methods}

Warangal urban is one of the districts having significant number of handloom weaving population in Telangana state and known place for durrie weaving. Warangal urban was purposively chosen to study the socioeconomic status of durrie weavers. The sample size of 120 respondents was randomly selected out of 1700 weavers present in that area. Self-developed interview schedule was used to elucidate the information required. Income, educational qualification, and profession were taken into consideration to compute socioeconomic status as per modified Kuppuswamy's socio economic scale2018.Data was analysed by frequency, percentage and correlation.

\section{Results and Discussion}

Study revealed that eighty two per cent of the respondents were men and the remaining eighteen per cent of the respondents were women. Among 98 male respondents 52 per cent of the respondents were having age above 51 years and 45 per cent of the respondents were in between the age of 29 to 51 years. Only 2 per cent of the respondents were age less than 29 years old. Among 22 female respondents 77 per cent of the respondents belong to the age group of 29 to 51 years. This shows that percentage of young generation involvement in this occupation was declining (Table 1).

Out of the total male respondents around 31 per cent of the respondents were illiterate; nearly 27 per cent of the respondents were having education up to middle school level, 19 and 18 per cent of the respondents were having education up to primary level and high school level respectively. Negligible per cent of the respondents were having education up to intermediate and graduate level. Thirty six per cent of the female respondents were having education up to high school level. Approximately 32 per cent of the female respondents were illiterate. In total almost 31 per cent of the respondents were illiterate. One-fourth of the respondents were having education up to middle school level; nearly 22 and 18 per cent of the respondents were having education up to high school and primary level respectively (Table 2 ).

Out of 98 male respondents around 90 per cent of the respondents were from small size family. Cent per cent of the female respondents belonged to small family size. In total nearly 92 per cent of the respondents were from small size family and negligible per cent of the respondents were from medium $(5.83 \%)$ and large $(2.50 \%)$ family size (Table $3)$.

Table 4 revealed that around 84 and 68 per cent of the male and female respondents were having monthly income in the range of 20926213 Rs. In other words around 81 per cent of the total respondents i.e male and female together were having income between 20926213 Rs. Negligible per cent of the respondents were having income between 6214- 10356 and less than 2091 respectively.

The data indicated that around 94 per cent of the male respondent and 77 per cent of the female respondents were having membership in handloom co-operative society. Out of total sample, 92 per cent of the respondents were having membership in handloom co-operative society and all were in member position (Table 5).

Nearly 47 and 64 per cent of the male and female respondents were availing support from the government (Table 6). From the beneficiaries almost 40 per cent of the male and 51 per cent of the female respondents were availing welfare scheme named as Thrift fund cum saving and security scheme. In total 
43 per cent of the respondents were availing Thrift fund cum saving and security scheme and only 7 per cent of the respondents were having health insurance.

Table 7 and 8 summarized the BMI and Body type of the selected weavers. Around 49 per cent of the male respondents and 59 per cent of the per cent of female respondents were having normal body weight and mesomorph body type.

Thirty per cent of the male respondents and around 23 per cent of the female respondents were having underweight and ectomorph body type. Less than 20 per cent of the respondents out of total sample were having over weight and negligible per cent of the respondents were having obesity.

Table 9 depicted the daily working hours of weavers. About 61.22 per cent of the male respondents and thirty nine per cent of the female respondents were working for 6-8 hours/day.
Whereas out of total sample 22 and 18 per cent of the respondents work for more than 8hours/day and less than6hours/day respectively (Table 10).

Seventy one per cent of the male respondents were having more than 25 years of work experience and 68 per cent of the female respondents were having work experience between 5-10 years (Table 11). Negligible per cent of the female respondents were having experience more than 25 years. Over all 60 per cent of the respondents were having work experience above 25 years.

Nearly 75 per cent of the male and 73 per cent of the female respondents didn't have their own looms and they were working as wage workers. On an aggregate around 12 per cent of the respondents were having two looms and negligible per cent of the respondents were having one $(6.66 \%)$, five and above $(3.33 \%)$, four $(2.5 \%)$ and three $(1.66 \%)$ respectively (Table 12).

Table.1 Distribution of weavers by age

\begin{tabular}{|r|l|l|l|l|}
\hline S.no & Age & Male $(\mathbf{n = 9 8})$ & Female $(\mathbf{n = 2 2})$ & Total $(\mathbf{n = 1 2 0})$ \\
\hline 1. & Less than 29 years & $2(2.04)$ & $5(22.72)$ & $7(5.83)$ \\
\hline 2. & 29 to 51 years & $45(45.19)$ & $17(77.27)$ & $62(51.66)$ \\
\hline 3. & More than 51 years & $51(52.04)$ & -- & $51(42.50)$ \\
\hline
\end{tabular}

*Figures in parenthesis indicate the percentage values

Table.2 Distribution of weavers by education

\begin{tabular}{|r|l|l|l|l|}
\hline S.no & Education & Male $(\mathbf{n = 9 8})$ & Female $(\mathbf{n = 2 2})$ & Total $(\mathbf{n = 1 2 0})$ \\
\hline $\mathbf{1 .}$ & Illiterate & $30(30.61)$ & $7(31.81)$ & $37(30.83)$ \\
\hline $\mathbf{2 .}$ & Primary school certificate & $19(19.38)$ & $2(9.09)$ & $21(17.50)$ \\
\hline $\mathbf{3 .}$ & Middle school certificate & $26(26.53)$ & $4(18.18)$ & $30(25.00)$ \\
\hline $\mathbf{4 .}$ & High school certificate & $18(18.36)$ & $8(36.36)$ & $26(21.66)$ \\
\hline $\mathbf{5 .}$ & $\begin{array}{l}\text { Intermediate or post high } \\
\text { school diploma }\end{array}$ & $4(2.08)$ & $1(4.54)$ & $5(4.166)$ \\
\hline 6. & Graduate or post graduate & $1(1.020)$ & -- & $1(0.83)$ \\
\hline 7. & Profession or honors & -- & -- & -- \\
\hline
\end{tabular}

*Figures in parenthesis indicate the percentage values 
Table.3 Distribution of weavers by family size

\begin{tabular}{|r|l|l|l|l|}
\hline S.no & Family size & Male $(\mathbf{n = 9 8})$ & Female $(\mathbf{n = 2 2})$ & Total $(\mathbf{n = 1 2 0})$ \\
\hline $\mathbf{1 .}$ & $\begin{array}{l}\text { Small(less than } 4 \\
\text { members) }\end{array}$ & $88(89.79)$ & $22(100.00)$ & $110(91.66)$ \\
\hline 2. & Medium (4-8 members) & $7(7.14)$ & -- & $7(5.83)$ \\
\hline 3. & Larger ( more than 8) & $3(3.06)$ & -- & $(2.50)$ \\
\hline
\end{tabular}

* Figures in parenthesis indicate the percentage values

Table.4 Distribution of weavers by monthly income

\begin{tabular}{|r|l|l|l|l|}
\hline S.no & Monthly income & Male $(\mathbf{n = 9 8})$ & Female $(\mathbf{n = 2 2})$ & Total $(\mathbf{n = 1 2 0})$ \\
\hline $\mathbf{1 .}$ & $<2091$ & $4(4.08)$ & $6(27.27)$ & $10(8.33)$ \\
\hline $\mathbf{2 .}$ & $2092-6213$ & $82(83.67)$ & $15(68.18)$ & $97(80.83)$ \\
\hline $\mathbf{3 .}$ & $6214-10356$ & $12(12.24)$ & $1(4.54)$ & $13(10.83)$ \\
\hline $\mathbf{4 .}$ & $10357-15535$ & -- & -- & -- \\
\hline $\mathbf{5 .}$ & $15536-20714$ & -- & -- & -- \\
\hline $\mathbf{6 .}$ & $20715-41429$ & -- & -- & -- \\
\hline
\end{tabular}

*As per modified Kuppuswamy's Socio-Economic Status Scale 2018

* Figures in parenthesis indicate the percentage values

Table.5 Distribution of weavers by membership and position in handloom co-operative society

\begin{tabular}{|r|l|l|l|l|}
\hline S.no & $\begin{array}{l}\text { Membership in handloom co- } \\
\text { operative society }\end{array}$ & Male $(\mathbf{n = 9 8 )}$ & Female $(\mathbf{n = 2 2})$ & Total $(\mathbf{n = 1 2 0})$ \\
\hline $\mathbf{1 .}$ & Yes & $93(91.66)$ & $17(77.27)$ & $110(91.66)$ \\
\hline & Positions in handloom society & & & \\
\hline $\mathbf{1 .}$ & President & -- & -- & -- \\
\hline 2. & Secretary & -- & -- & -- \\
\hline 3. & Member & $93(91.66)$ & $17(77.27)$ & $110(91.66)$ \\
\hline 4. & $\begin{array}{l}\text { Any other position (please } \\
\text { specify }\end{array}$ & -- & -- & - \\
\hline
\end{tabular}

*Figures in parenthesis indicate the percentage values

Table.6 Distribution of weavers by Government support in terms of fiscal and health

\begin{tabular}{|r|l|l|l|l|}
\hline S.no & $\begin{array}{l}\text { Government support in } \\
\text { terms of fiscal and health }\end{array}$ & Male $(\mathbf{n = 9 8 )}$ & Female $(\mathbf{n = 2 2})$ & Total $(\mathbf{n = 1 2 0})$ \\
\hline 1. & Yes & $46(46.93)$ & $14(63.63)$ & $60(50.00)$ \\
\hline 2. & No & $52(53.06)$ & $8(36.36)$ & $60(50.00)$ \\
\hline & Type of support & & & \\
\hline 1. & Health insurance & $7(7.14)$ & $1(4.54)$ & $8(6.66)$ \\
\hline 2. & Medical support & -- & -- & -- \\
\hline 3. & Yarn subsidy & -- & -- & -- \\
\hline 4. & Any other (Trift fund) & $39(39.74)$ & $13(59.09)$ & $52(43.33)$ \\
\hline
\end{tabular}

*Figures in parenthesis indicate the percentage values 
Table.7 Distribution of weavers by BMI

\begin{tabular}{|c|c|c|c|c|}
\hline S.no & BMI & Male $(n=98)$ & Female $(n=22)$ & Total $(\mathbf{n}=\mathbf{1 2 0})$ \\
\hline 1. & Under weight (18.5 or less) & $30(30.16)$ & $5(22.72)$ & $35(29.16)$ \\
\hline 2. & $\begin{array}{l}\text { Normal weight ( } 18.5 \text { to } \\
24.99 \text { ) }\end{array}$ & $48(48.97)$ & $13(59.09)$ & $61(51.83)$ \\
\hline 3. & Over weight(25 to 29.99$)$ & $19(19.38)$ & $4(18.18)$ & $23(19.16)$ \\
\hline 4. & $\begin{array}{l}\text { Obesity (class 1) (30 to } \\
34.99)\end{array}$ & $1(1.02)$ & -- & $1(0.83)$ \\
\hline 5. & $\begin{array}{l}\text { Obesity (class } 2) \text { ( } 35 \text { to } \\
39.99)\end{array}$ & -- & -- & -- \\
\hline 6. & $\begin{array}{l}40 \text { or greater (Morbid } \\
\text { obesity) }\end{array}$ & -- & -- & -- \\
\hline
\end{tabular}

* As per WHO, 2010.

Table.8 Distribution of weavers by body type

\begin{tabular}{|r|l|l|l|l|}
\hline S.no & Body types & Male $(\mathbf{n = 9 8})$ & Female $(\mathbf{n}=\mathbf{2 2})$ & Total $(\mathbf{n = 1 2 0})$ \\
\hline $\mathbf{1 .}$ & Ectomorph & $30(30.66)$ & $5(22.72)$ & $35(29.16)$ \\
\hline 2. & Mesomorph & $48(48.97)$ & $13(59.09)$ & $61(51.83)$ \\
\hline 3. & Endomorph & $20(20.40)$ & $4(18.18)$ & $24(20.00)$ \\
\hline
\end{tabular}

* Figures in parenthesis indicate the percentage values

Table.9 Distribution of weavers by working hours/day

\begin{tabular}{|r|c|l|l|l|}
\hline S.no & Working hours/day & Male $(\mathbf{n = 9 8})$ & Female $(\mathbf{n = 2 2})$ & Total $(\mathbf{n = 1 2 0})$ \\
\hline $\mathbf{1 .}$ & Less than 6hrs & $13(13.26)$ & $8(36.36)$ & $21(17.5)$ \\
\hline $\mathbf{2}$. & 6-8 hrs & $60(61.22)$ & $13(39.09)$ & $73(60.83)$ \\
\hline 3. & More than 8 hrs & $25(25.51)$ & $1(4.54)$ & $26(21.66)$ \\
\hline
\end{tabular}

* Figures in parenthesis indicate the percentage values

Table.10 Distribution of weavers by work experience

\begin{tabular}{|r|l|l|l|l|}
\hline S.no & Years of experience & Male $(\mathbf{n = 9 8})$ & Female $(\mathbf{n = 2 2})$ & Total $(\mathbf{n = 1 2 0})$ \\
\hline $\mathbf{1 .}$ & $5-10$ years & $3(3.06)$ & $15(68.18)$ & $18(15.00)$ \\
\hline $\mathbf{2 .}$ & $10-15$ years & $6(6.12)$ & $2(9.09)$ & $8(6.66)$ \\
\hline $\mathbf{3 .}$ & $15-20$ years & $6(6.12)$ & $2(9.09)$ & $8(6.66)$ \\
\hline $\mathbf{4 .}$ & $20-25$ years & $13(3.26)$ & $1(4.54)$ & $14(11.66)$ \\
\hline $\mathbf{5 .}$ & 25 years and above & $70(71.42)$ & $2(9.09)$ & $72(60.00)$ \\
\hline
\end{tabular}

* Figures in parenthesis indicate the percentage values 
Table.11 Distribution of weavers by loom ownership

\begin{tabular}{|c|c|c|c|c|}
\hline S.no & Number of looms owned & Male (n=98) & Female $(n=22)$ & Total $(n=120)$ \\
\hline 1. & Nil & $73(74.8)$ & $16(72.72)$ & $89(74.16)$ \\
\hline 2. & One & $7(7.14)$ & $1(4.54)$ & $8(6.66)$ \\
\hline 3. & Two & $11(11.22)$ & $3(13.63)$ & $14(11.66)$ \\
\hline 4. & Three & $2(2.04)$ & -- & $2(1.66)$ \\
\hline 5. & Four & $3(3.06)$ & -- & $3(2.50)$ \\
\hline 6. & Five and above & $2(2.0)$ & $2(9.09)$ & $4(3.33)$ \\
\hline
\end{tabular}

* Figures in parenthesis indicate the percentage values

Table.12 Distribution of weavers by Socio economic status

\begin{tabular}{|r|l|l|l|l|}
\hline S.no & Socio- economic classes & Male $(\mathbf{n = 9 8})$ & Female $(\mathbf{n = 2 2})$ & Total $(\mathbf{n = 1 2 0})$ \\
\hline $\mathbf{1 .}$ & Upper & -- & -- & -- \\
\hline $\mathbf{2 .}$ & Upper middle & - & -- & - \\
\hline 3. & Lower middle & $10(10.20)$ & $2(9.09)$ & $12(10.00)$ \\
\hline $\mathbf{4 .}$ & Upper lower & $88(89.79$ & $20(90.90)$ & $108(90.00)$ \\
\hline $\mathbf{5 .}$ & Lower & -- & -- & -- \\
\hline
\end{tabular}

*As per modified Kuppuswamy's Socio-Economic Status Scale 2018

* Figures in parenthesis indicate the percentage values

Table.13 Relationship between BMI, working hours and socio-economic status of weavers

\begin{tabular}{|r|l|c|c|c|}
\hline S.no & \multicolumn{1}{|c|}{ Variables } & N & $\begin{array}{c}\text { Correlation } \\
\text { coefficient }\end{array}$ & Remarks \\
\hline $\mathbf{1 .}$ & $\begin{array}{l}\text { BMI and socio- } \\
\text { economic status }\end{array}$ & 120 & $0.0512^{* *}$ & Significant \\
\hline $\mathbf{2 .}$ & $\begin{array}{l}\text { Working hours and } \\
\text { socio-economic } \\
\text { status }\end{array}$ & 120 & $0.068^{* *}$ & Significant \\
\hline
\end{tabular}

** Significant at $1 \%$ levels of significance

Majority of the male $(89.79 \%)$ and female $(90.90 \%)$ respondents were in the upper lower category. Over all 90 per cent of the respondents were in the upper lower socio economic category and 10 per cent of the respondents were in the lower middle category.

There is a significant positive relationship between socio-economic status and BMI, with $\mathrm{r}(118)=0.0512, \mathrm{p}<0.1$. It can be inferred that individuals who have high socio economic status will have high BMI which means that those earn more they can spend more on food and health. There is a significant positive relationship between socio-economic status and working hours, with $\mathrm{r}(118)=0.068, \mathrm{p}<0.1$. It can be concluded that individuals who spend active time on weaving will earn some amount of remuneration, so automatically socioeconomic status of the individual will be enhanced (Table 13). 
It can be concluded from the present research that handloom weaving operation is dominated by male weavers those who aged above 51 years. Middle aged women were highly involved in weaving. When compared men, three-fourth of the women weavers from small size family. Majority of the weavers monthly income is less than 6000rs, the main reason is most of the workers were working as wage worker. Women weavers showed high interest in saving. When compared to women weavers, men weavers were more in numbers in underweight category which specifies that malnutrition and other health problems. Most of the weavers were in the upper lower socio-economic category which indicates that they were poor. The handloom industry is mostly household based occupation so it carried out by the family members. Low wages of weavers increase the percentage of migration to other occupations and weavers were forced to leave this occupation. Young weavers have to be motivated to come forward to sustain this sector by introducing special initiatives. There should be simplified terms and conditions for security loans for fixed capital, working capital and other forms of assistance at subsidized interest rates.

\section{References}

Department of handlooms and textiles, http://handtex.telangana.gov.inretrived on 12/01/2019 Craft council of India, 2016 retrieved on 2/02/2019

Directorate general of commercial intelligence and statistics (DGCIS). Retrieved on 2/02/2019 Modified Kuppuswamy's socio-economic scale 2018.

\section{How to cite this article:}

Gayathri Devi, M., V. Vijaya Lakshmi, Induri Rajitha and Kameswari, S.L. 2019. Socio Economic Status of Handloom Weavers in Warangal Urban District. Int.J.Curr.Microbiol.App.Sci. 8(03): 690-696. doi: https://doi.org/10.20546/ijcmas.2019.803.085 